\title{
Variasi Leksikal Bahasa Bali Dialek Kuta Selatan
}

\author{
PUTU DEVI MAHARANI ${ }^{1}$, KOMANG DIAN PUSPITA CANDRA ${ }^{2}$ \\ 1,2. Program Studi Sastra Inggris, Sekolah Tinggi Bahasa Asing (STIBA) Saraswati Denpasar \\ E-mail : vee_maharani86@yahoo.com,miss_puspita@yahoo.com
}

\begin{abstract}
Bahasa daerah merupakan kekayaan budaya yang perlu dilestarikan. Bahasa Bali menjadi salah satu bahasa daerah di Indonesia yang sangat kaya dengan kosakata. Untuk menyebutkan satu entitas seringkali kita temui berbagai variasi penyebutannya di masyarakat yang tinggal pada wilayah yang berbeda di Bali padahal mereka menggunakan bahasa yang sama yaitu bahasa Bali. Variasi penyebutan suatu entitas ini terkadang menjadi sesuatu yang terdengar aneh atau kurang dimengerti oleh penutur bahasa Bali yang berasal dari daerah yang berbeda namun menjadi ciri dan identitas daerah mereka yang dapat menghasilkan atmosfer kekeluargaan dan keakraban saat dipergunakan. Penelitian ini bertujuan untuk mendeskripsikan variasi leksikal bahasa Bali di daerah Kuta bagian Selatan khususnya daerah Ungasan, Jimbaran dan Kedonganan yang saat ini menjadi salah satu tempat tujuan wisata di Bali serta untuk memetakan bagaimana perkembangan variasi pilihan kata masyarakat lokal daerah tersebut setelah banyaknya interaksi dengan wisatawan asing dan lokal yang datang ke daerah Kuta bagian Selatan ini, sehingga rumusan masalah dalam penelitian ini adalah a) Bagaimana penggunaan variasi leksikal bahasa Bali di daerah Jimbaran, Ungasan dan Kedonganan dan b) Pada kelas kata apa saja variasi leksikal yang terjadi. Metode pengumpulan data yang digunakan dalam penelitian ini adalah metode simak dengan teknik sadap, teknik libat cakap, teknik bebas libat cakap, teknik rekam dan teknik catat serta metode cakap dengan teknik pancing yang menjadi acuan dalam menemukan tujuan penelitian. Dari hasil analisis tiga dialek bahasa Bali daerah Kuta bagian Selatan ini, ditemukan beberapa variasi leksikal dalam kelas kata pronominal, nomina, kata sifat, kata kerja dan kata keterangan. Kemunculan variasi leksikal untuk kelas kata nomina muncul paling dominan. Pada dialek Jimbaran dan Kedonganan banyak ditemukan penggunaan leksikal yang sama. Pada dialek Ungasan ditemukan lebih banyak perbedaan leksikal yang digunakan untuk merujuk suatu yang sama.
\end{abstract}

Kata kunci : variasi; leksikal; bahasa Bali

\section{Lexical Variation of Balinese Language South Kuta Dialect}

Language describes the culture of local society because in cultural activity, the community has utilizes the language as a tool of interaction. Balinese language is a traditional language spoken by the local people of Bali. Differences or variations in the use of Balinese language can be observed in each district on the levels of sound, morphology, syntax and lexicon. The variations in Balinese language gives particular dialects unique to each region. This aims of this study is to find out the lexical variations in three different areas namely, Jimbaran, Kedonganan and Unggasan. The method of collecting the data in this research are close observation method which refers to the technique of tapping, face-to-face interview technique, eaves-dropping technique, recording and note-taking technique. Generally found there are some lexical variations found in these three areas used to mention the same things. The lexical variations found are in class of pronoun, noun, verb, adjective, and adverbial. The dominant variation is noun. Jimbaran and Kedonganan hold similarity in lexical choice. Unggasan holds many differences from the other areas owing to the geographical location of this village in its highlands position.

Key words : variation; lexical; Balinese language 


\section{PENDAHULUAN}

Bahasa menggambarkan budaya masyarakat penuturnya karena dalam kegiatan berbudaya, masyarakat tidak pernah lepas dari bahasa sebagai alat interaksi. Bahasa dan budaya memiliki korelasi yang sangat erat. Bahasa dipandang sebagai suatu sumber daya untuk menyingkap misteri budaya, mulai dari perilaku berbahasa, identitas, dan kehidupan penutur, pendayagunaan, dan pemberdayagunaan bahasa sampai dengan pengembangan serta pelestarian nilainilai budaya (Yadnya, 2004:52). Hal ini sejalan dengan pendapat Kramsch (1998:3) yang menyebutkan tiga hal yang terjalin erat antara bahasa dan budaya, yakni (1) language expresses cultural reality, (2) language embodies cultural reality, dan (3) language simbolizes cultural reality.

Perkembangan budaya tentu berpengaruh terhadap bahasa yang dipergunakan penuturnya. Saat ini kebanyakan masyarakat, terutama masyarakat usia muda sangat jarang ditemukan berkomunikasi dengan mempergunakan bahasa daerahnya. Bahkan tak jarang mereka tidak bisa menggunakan bahasa daerahnya sendiri karena terbiasa menggunakan bahasa Indonesia ataupun bahasa asing seperti misalnya bahasa Inggris. Budaya menggunakan bahasa Indonesia ataupun bahasa Inggris pada anak-anak tidak saja terjadi di daerah perkotaan, di pedesaan pun para orangtua mengajak anak-anaknya berbicara menggunakan bahasa Indonesia. Penggunaan bahasa nasional atau internasional di sekolah maupun di lingkungan sekitar terkadang membuat mereka susah untuk mengutarakan sesuatu dalam bahasa Bali. Fenomena ini juga tidak jarang terjadi pada masyarakat usia tua, karena tingginya tingkat mobilitas dan lingkungan sekitar yang menggunakan bahasa Indonesia ataupun bahasa Inggris mereka terkadang dan bahkan banyak melakukan campur kode bahasa dalam bercakap.

Penelitian ini mencoba menelusuri penggunaan bahasa Bali di daerah Kuta bagian Selatan yang saat ini merupakan salah satu pusat pariwisata di Bali. Pada daerah Kuta bagian Selatan menjadi pusat pariwisata bahari, karena letaknya berdekatan dengan pantai. Pantai Kuta terkenal dengan pasir putihnya yang sangat diminati oleh wisatawan lokal maupun asing. Banyaknya wisatawan lokal maupun asing ke daerah Kuta bagian Selatan ini juga karena banyaknya pusat perbelanjaan untuk fashion, asesoris, cafe, restoran dan hotel. Banyaknya wisatawan yang datang baik lokal maupun internasional tentunya menyebakan banyaknya interaksi masyarakat lokal dengan wisatawan dari berbagai daerah di luar Bali. Interaksi yang terjadi terus-menerus tentunya akan berpegaruh terhadap budaya masyarakat lokal. Budaya yang dimaksud selain perilaku atau sikap tentunya bahasa menjadi hal yang paling banyak memperoleh pengaruh. Variasi leksikal dalam berkomunikasi tentu akan terjadi karena adanya interaksi ini. Dalam penelitian ini tiga kecamatan di darah Kuta bagian Selatan dipilih sebagai pusat penelitian, yaitu desa Jimbaran, Ungasan dan Kedonganan, untuk melihat sejauh mana pengaruh bahasa Indonesia dan asing lainnya terhadap dialek bahasa Bali yang masing-masing daerah ini miliki. Dari fenomena yang dipaparkan diatas, penelitian ini dirasa perlu dilakukan untuk lebih dalam mengetahui: a) Bagaimana penggunaan variasi leksikal tersebut dalam bahasa Bali di daerah Jimbaran, Kedonganan dan Ungasan? b) Pada kelas kata apa sajakah variasi leksikal bahasa Bali dialek Kuta Selatan ditemukan? Melalui penelitian ini diharapkan dapat memberikan sumbangsih terhadap penelitian tentang budaya berbahasa pada masyarakat Bali, sehingga dapat memperkenalkan variasi bahasa Bali dialek Bali Selatan kepada penutur bahasa Bali dari luar wilayah dan dapat menjadi jejak rekam sebelum dialek-dialek asli yang dimiliki semakin memudar karena terjadinya interaksi dengan budaya maupun bahasa dari daerah lain.

\section{METODE PENELITIAN}

Metode dan teknik pengumpulan data, sangat tergantung kepada jenis data yang dikumpulkan. Data yang digunakan dalam penelitian ini adalah data primer berupa ujaran lisan yang dituturkan oleh informan. Data lisan ini diperoleh dengan cara wawancara, observasi-partisipasi dan dokumentasi. Sumber data dari masing-masing daerah diambil 10 sampel penutur yang terdiri dari penutur dengan usia tua ( $>50 \mathrm{thn})$ yang tidak pernah keluar dari daerahnya dan pendidikan rendah (di tandai dengan TNM), penutur usia tua ( $>50$ thn) yang sering keluar daerah dan berpendidikan minimal SMP (ditandai dengan TM), dan penutur usia muda (17-40thn) yang sering keluar dari daerahnya (ditandai dengan $M$ ). Untuk itu metode yang digunakan dalam pengumpulan data adalah metode simak dan metode cakap (Sudaryanto,1993). Teknik yang digunakan adalah teknik elisitasi (teknik pancing), perekaman dan pencatatan. Untuk menggali informasi lebih dalam dan menguji keabsahan dari data yang diperoleh perlu dilakukan teknik wawancara semi terstruktur terhadap narasumber.

\section{ANALISIS DAN INTERPRETASI DATA}

\section{Penggunaan Variasi Leksikal Bahasa Bali Dialek Kuta Selatan}

Pada dialek Bahasa Bali Selatan khususnya pada daerah Kedonganan, Jimbaran dan Ungasan terdapat variasi leksikon yang ditemukan. Walaupun daerah-daerah ini sangat berdekatan dan dalam satu daer- 
ah kecamatan yang sama terdapat beberapa variasi kata dalam mengungkapkan sesuatu yang menyebabkan kekhasan dialek daerah mereka masing-masing. Berikut ini contoh penggunaan variasi leksikal tersebut dalam bahasa Bali dialek Kuta Selatan.

\section{Data 1}

\section{LT : Néng kijo éngko busan? (kemana tadi kamu?)}

P : kému nang Kangin, sik dadonge bedangin, Kubu Géde, nélokin I dadong ajak I kak. Iyé sébét kone bayunne ngélah mantu lakento, pragat ngambul. Apé kaden tagingé sébénarne. Ongong ati ne bén né tawang. Jég taanan I kak. Pédalém lakento, pontang-panting ngalih gae. Aruh.. ake ménéng kangén népukin I kak, wah ti taananne nok kamu, ck... $\operatorname{aruuh...}$

(kesana ke Timur, ke nenek di Timur, Kubu Géde, nengok nenek dan kakek. Dia sedih katanya punya menantu seperti itu, selalu ngambek. Tidak tau apa sebenarnya yang diinginkan. Malas jadinya perasaanku tahu. Menderita kakek. Kasihan seperti itu, pontang-panting mencari kerja. Aduuh aku kasihan melihat kakek, banyak sekali penderitaannya tau kamu, ck... aduuh...)

LT : Téro milu-milu po... Pas yo awake kému, kengenang népukin. Kene jé,, sébénarne népukin panak kitik ménéng kému. Pas yé I dadong nyatué lakento, dingoang jé masih. Kento doen jé masih aku kijo pé masih. Ditu doen ngoyong.

(tidak ikut-ikut dah,, pas saja nenek cerita begitu, dengarkan juga. Begitu saja, kemana juga aku. Disitu saja diam.)

(Sumber: Bahasa Bali Dialek Unggasan)

Pada dialek Ungasan data 1 variasi leksikal yang ditemukan adalah kata /kijo/ (kemana) dimana dalam bahasa Bali standar adalahkija/kij@/, kata keto yang berarti 'begitu' di Ungasan disebut dengan kento ataulakento, tagiha/tagih@/'diminta'disebut dengan taginga /tagiNo/, kenkenang 'dibagaimanakan' disebut dengan kengenang. 'Kamu' yang dalam bahasa Bali standar disebut dengan ragane atau dalam ragam akrab sering disebut dengan $c i$ dalam dialek Ungasan disebut dengan éngko. Dalam menyebut diri sendiri yaitu "saya" leksikal bahasa Bali yang digunakan di daerah Ungasan ini sama dengan bahasa Indonesia yaitu $a k u$ dengan variasi tambahan wake dan ake, dimana bahasa Bali standar yang biasa digunakan kebanyakan daerah di Bali adalah tyang atau cang dalam ragam akrabnya. Variasi leksikal tersebut dapat juga dilihat pada percakapan dialek Unggasan dibawah ini:

\section{Data 2}

LT : bé mulih éngko Ta? (sudah pulang kamu Ta?)

P: bé,,, maré te mulih (sudah,, baru saja pulang)

LT: adi ngenggal éngko mulih? (kenapa cepat kamu pulang?)

P : enggal, kengen mékélo-mékélo dini..

(cepat, mengapa juga lama-lama di sini)

LT : emang jam kudo jani ne?

(memang jam berapa sekarang ini?)

P : subo jam pat ne...(sudah jam empat ini,,,)

LT : aruh... antiang nake aku (aduuuh, tunggu dong saya)

$\mathrm{P}$ : kél kijo mulih engko? (mau kemana pulang kamu?)

LT : melali ... sing melali? (lancong... tidak lancong?)

$\mathrm{P}$ : kijo melali? (kemana lancong?)

LT : ké kubon ni ne binjép aku (ke rumah sebentar lagi saya)

$\mathrm{P}$ : ihh, sing juari cang

(iihh... malu saya)

LT : adi kento? (kenapa begitu??)

(Sumber: Bahasa Bali Dialek Unggasan)

Variasi leksikal yang berbeda dapat kita temukan di daerah tetangganya yaitu daerah Jimbaran dan Kedonganan yang berada pada kecamatan yang sama dengan daerah Ungasan. Pada daerah Jimbaran, untuk menyebut kata "saya": tyang yang dalam dialek Ungasan disebut dengan variasi aku, wake dan ake ditemukan variasi leksikal "oke". Variasi penyebutan leksikal oke untuk kata saya/tyang tersebut dapat kita lihat dalam data dialog berikut ini:

\section{Data 3}

LT : halo... dijé ne? (halo .... Dimana ini?)

P : Ci jumah? (kamu di rumah?)

LT : sing,,, pidan kumpul ajak timpal-timpalé?

(tidak,, kapan kumpul dengan teman-teman?) 
$\mathrm{P}$ : oke bin pidan gen nyidang, ci pidan nyidang?

(saya kapan saja bisa, kamu kapan bisa?)

LT : akhir bulan nyak? (akhir bulan yuk?)

$\mathrm{P}:$ nah, keneang gen naa.. oke kan siap gen

(iya,, atur saja ya,, saya kan siap saja)

LT : Eh, ci dijé megae jani?

(eh,, kamu dimana bekerja saat ini?)

$\mathrm{P}:$ nyen? (siapa?)

LT : kamu,, (kamu,,)

P : aku megae tuni (saya kerja tadi)

LT : dijé megae kamu? (dimana kerja kamu?)

P : di kene.. di Nusé dué oke (di gini,„, di Nusa Dua saya)

LT : Nusé dué ijé? Halo,, (di Nusa Dua mana? Halo,„,)

P : di... itu lo,,, di Pasic Holliday (di,,, itu loh,, di Pasic Holliday)

LT : o...(oh,,.)

P : eh ci ké kubon ke ne? (eh kamu ke rumah saya?)

LT : apé to? (bingung dengan arti kalimat yang disebutkan) (apa itu?)

P : ci ke kubon ke ne? (kamu ke rumah saya?)

LT : ke kubon ci ne ? (sambil berpikir, menerka dan memastikan) ( ke rumah mu?)

P : cénik gae to, cai képanggang $\boldsymbol{k e}$, nyak ke...(gampang itu, kamu saya panggang, mau kamu...)

LT : jénéng ci ne!! nah.. nah.. wkwk (tampangmu!! Ya,, ya,, wkwkwkwk)

B : wkwkwk yuk (wkwkwkwk yuk)

Elisa : nah.. yuk.. (ya.. yuk...)

(Sumber: Bahasa Bali Dialek Jimbaran)

Variasi leksikal yang ditemukan juga pada percakapan antar teman untuk penutur dari daerah Jimbaran adalah penyebutan kata 'rumah' yang biasanya disebut ' $u m a h$ ' atau ' $k u b u$ ' untuk merendah dalam bahasa Bali, namun di Jimbaran sering disebut dengan 'kubon'. Pada percakapan tersebut penutur yang merupakan masyarakat asli Jimbaran sangat sering menyebutkan kata oke atau disingkat menjadi ke untuk menyebut dirinya (aku/saya) yang dalam bahasa Bali lumbrah disebut dengan tyang atau cang. Namun penggunaan oke tersebut biasanya digunakan dalam pembicaraan santai antara anak muda yang memiliki hubungan akrab. Kata tyang lebih dominan digunakan oleh masyarakat usia yang lebih tua, misalnya dalam percakapan data 4 berikut ini:

\section{Data 4}

P : hai,,, cantiknya buk Agung tyang é

LT : selamat siang

P : cantik sekalee,,, kalo dibilang ganteng nantik salah, bencong namanya,

LT : napi niki? Ih, babi

P : seperti biasa nggih?

LT : nggih

$\mathrm{P}$ : lawar daging é buk Agung

LT : dagingin, sambel aja gak usah, niki sama telor. Mana asisten nik?

$\mathrm{P}:$ ampun mulih

LT : megae?

P : nggih,, adeng-adeng kanggeang buk

LT : makasi nik,

(Sumber: Bahasa Bali Dialek Jimbaran)

Variasi kata ganti atau promina juga ditemukan pada daerah Jimbaran, yaitu kata 'kamu' yang dalam bahasa Bali kepara umumnya disebut dengan cai atau ci, pada dialek Jimbaran ditemukan variasi kata béné untuk menyebut kata kamu selain kata cai dan ci pada kondisi informal yang diutarakan oleh seseorang kepada lawan tuturnya yang sudah dikenal dekat. Data tersebut diperoleh dari data percakapan berikut ini.

\section{Data 5}

LT : LPD hari Minggu jani é?, adé yé bank mégae? (LPD sekarang hari Minggu ya? Ada tidak bank yang bekerja?) 


\section{$\mathrm{P}$ : apé to apé ? (apa itu apa?)}

LT : yé kéréng mai yé LPD Sabtu é? (mereka sering kesini ya hari Sabtu?)

P : kéréng mai,,, mai,,.. Jam kudé ne jani ? adé sing bank mai nang besik é. Tonden adé mai. Jég jang pipise ditu engken? Daripada abé.. nyanan télah, sing béné ngélah pis

(sering kesini,,, sini,„.. Jam berapa ini sekarang? Tidak ada bank kesini satupun. Belum ada kesini. Ya taruh uangnya disana saja bagaimana? Daripada dibawa.. nanti habis, tidak punya uang nanti kamu.)

\section{LT : nah (ya)}

\section{P : koprasi ne baang? (koperasinya ini kasih?)}

LT : aé..(iya)

P : konyangan? Nah-nah. Adi nyah-nyahan keto nabung, nak bék ngélah utang. Pedalém yé.. pédalém liu ngélah utang, daripada di sérég nyanan ilang yé Pak é?? Ajan tyang pédalém tyang to tinggélé naé,, nitip satak, satus,

(semua? Ya ya. Kenapa ragu-ragu begitu nabung, orang banyak punya hutang. Kasihan dia.. kasihan banyak punya hutang, daripada di laci nanti hilang itu Pak ya? Benar saya kasihan itu lihat saja, nitip dua ratus, seratus,,)

\section{(Sumber: Bahasa Bali Dialek Kedonganan)}

Kata béné yang berarti 'kamu' lebih sering disebut dengan éngko di daerah Ungasan dan di daerah Kedonganan sering disebut dengan ci atau cai dalam bahasa Bali kepara atau bahasa Bali yang digunakan dalam kondisi nonformal oleh sekelompok masyarakat yang memiliki hubungan kekerabatan yang dekat. Berikut ini adalah contoh percakapan masyarakat Jimbaran.

\section{Jenis Variasi Leksikal Bahasa Bali Dialek Kuta Selatan}

Variasi leksikal bahasa Bali dialek Kuta Selatan ditemukan melalui metode menyimak percakapan ataupun melakukan teknik pancing para penutur asli dialek Ungasan, jimbaran dan Kedonganan, dan juga dilakukan pengecekan beberapa leksikal yang diklasifikasikan menjadi: 1) bilangan dan ukuran, 2) waktu serta arah, 3) bagian tubuh manusia, 4) kata ganti orang dan kekerabatan, 5) pakaian dan perhiasan, 6) jabatan dan pekerjaan, 7) binatang dan bagian tubuhnya, 8) alam, 9) bau dan rasa, 10) sifat, keadaan dan warna, 11) alat, dan 12) aktifitas.

Variasi leksikal yang diperoleh pada ketiga daerah Kuta bagian Selatan ini, secara garis besar ditemukan pada bentuk kata ganti personal, verba, kata sifat dan kata keterangan. Variasi leksikal pada dialek Jimbaran, Kedonganan dan Ungasan selanjutnya akan diklasifikasikan berdasarkan kelas katanya, berdasarkan data yang diperoleh dari pengamatan langsung bebas libat cakap dan pengumpulan data melalui kuesioner dengan teknik libat cakap. Variasi leksikal yang ditemukan pada data percakapan di atas memperlihatkan bahwa pada dialek Jimbaran banyak kata-kata pada bahasa bali lumbrah atau baku mengalami pemenggalan, sehingga jika didengar oleh masyarakat penutur Bahasa Bali daerah Utara mungkin akan dianggap sangat aneh

\section{Variasi Leksikal Jenis Pronomina}

Berikut ini adalah variasi leksikal jenis kata pronominal yang ditemukan dalam dialek bahasa Bali dialek Kuta Selatan:

Variasi leksikal pada jenis kata ganti atau pronomina yang ditemukan pada dialek bahasa Bali Kedonganan, Ungasan dan Jimbaran adalah pada leksikal 'saya' dan 'kamu'. Penyebutan kata ganti untuk orang pertama ini ditemukan dengan variasi tyang, cang ake, aku dan oke. Kata tyang lebih dominan digunakan oleh masyarakat golongan usia tua, namun untuk di daerah Ungasan penyebutan kata 'saya' lebih banyak yang menyebut aku. Orangorang tua pun menyebut dirinya dengan aku saat bercakap-cakap dengan keluarga atau koleganya yang juga berasal dari Ungasan. Untuk golongan masyarakat yang berusia muda, penggunakaan variasi leksikal cang, rage dan ake sering digunakan, namun di daerah masyarakat golongan usia muda yang berasal dari Ungasan sangat mudah dikenali karena cenderung menyebut dirinya dengan $a k u$, dan untuk daerah Jimbaran penggunaan leksikal oke menjadi karakteristik tersendiri.

\section{Variasi Leksikal Jenis Kata Nomina}

Variasi leksikal yang paling banyak ditemukan pada dialek bahasa Bali daerah Ungasan, Jimbaran dan Kedonganan adalah pada jenis kata benda atau nomina. Variasi leksikal yang terjadi dalam penggunaannya ternyata ditemukan tidak saja variasi antar daerah namun masyarakat dalam satu daerahpun terkadang menyebutkan sesuatu dengan berbagai leksikal sesuai dengan tingkatan umur ataupun pendidikan dan kecenderungan mobilitas dari daerahnya. 
Tabel 1.

Variasi Leksikal Jenis Kata Pronominal Dialek Kuta Selatan

\begin{tabular}{|l|l|l|l|l|l|l|l|l|l|l|l|}
\hline \multirow{2}{*}{ No } & Jenis kata & \multicolumn{4}{|c|}{ Kedonganan } & \multicolumn{3}{c|}{ Jimbaran } & \multicolumn{3}{c|}{ Ungasan } \\
\cline { 2 - 11 } & Pronomina & TNM & TM & M & TNM & TM & M & TNM & TM & M \\
\hline 1 & Saya & Tyang & Tyang & Cang, ragé & tyang & Tyang & $\begin{array}{l}\text { Oke, } \\
\text { cang }\end{array}$ & Aku & aku & $\begin{array}{l}\text { Aku, ake, } \\
\text { cang }\end{array}$ \\
\hline 2 & Kamu & Béné & Béné & Cai & Béné & Béné & cai & Éngko & éngko & Éngko, cai \\
\hline
\end{tabular}

Tabel 2.

Variasi Leksikal Jenis Kata Nomina Dialek Kuta Selatan

\begin{tabular}{|c|c|c|c|c|c|c|c|c|c|c|}
\hline \multirow[t]{2}{*}{ No } & \multirow{2}{*}{$\begin{array}{l}\text { Jenis kata } \\
\text { Nomina }\end{array}$} & \multicolumn{3}{|c|}{ Kedonganan } & \multicolumn{3}{|l|}{ Jimbaran } & \multicolumn{3}{|l|}{ Ungasan } \\
\hline & & TNM & $\mathrm{TM}$ & M & TNM & $\mathrm{TM}$ & M & TNM & $\mathrm{TM}$ & M \\
\hline 1 & Payung & Pajéng & pajéng & Pajéng & pajéng & pajéng & pajéng & pajong & Pajong & pajong \\
\hline 2 & Topi & Capil & topong & Topong & topong & topong & topong & $\begin{array}{l}\text { Tetopong, } \\
\text { cecapil }\end{array}$ & $\begin{array}{l}\text { Teto- } \\
\text { pong, } \\
\text { topong }\end{array}$ & topong \\
\hline 3 & Cicak & Cécék & cécék & Cécék & cécék & cécék & cécék & cokcok & Cokcok & cokcok \\
\hline 4 & Ketombe & lampah & kétombe & kétombe & lampah & $\begin{array}{l}\text { Kétombe- } \\
\text { lampah }\end{array}$ & kétombe & $\begin{array}{l}\text { Kébun, } \\
\text { lampah }\end{array}$ & Kébun & kétombe \\
\hline 5 & Bara & Béé & béé & Béé & béé & Béé & béé & Bého, & Bého & Bého \\
\hline 6 & Cacar & Cangkrim & cangkrim & $\begin{array}{l}\text { Cangkrim, } \\
\text { cacar }\end{array}$ & cangkrim & cangkrim & $\begin{array}{l}\text { Cangkrim, } \\
\text { cacar }\end{array}$ & $\begin{array}{l}\text { Gumpan- } \\
\text { gan }\end{array}$ & $\begin{array}{l}\text { Gump- } \\
\text { angan, } \\
\text { cacar }\end{array}$ & Cacar \\
\hline
\end{tabular}

Pada tabel di atas dapat dilihat, variasi yang ditemukan cenderung memperlihatkan variasi pada penggunaan leksikal oleh masyarakat golongan usia muda yang banyak terpengaruh bahasa Indonesia dalam penyebutan bahasa Bali leksikal tertentu karena tidak pernah mendengar bahasa Balinya ataupun sangat jarang menggunakan bahasa Bali untuk leksikal tertentu tersebut dalam percakapan sehari-hari sehingga menggunakan leksikal yang sama dengan leksikal bahasa Indonesia dalam menyebutnya.

Misalnya kata 'cacar' yang dalam bahasa Bali disebut dengan cangkrim, beberapa responden berusia muda tetap menyebut leksikal tersebut dengan cacar dalam bahasa Bali dan beberapa masyarakat usia tua yang sering bepergian dan bergaul ke daerah lain pun juga menyebut dengan cacar. Namun masyarakat tua yang tidak pernah atau sangat jarang keluar dari daer- ahnya menyebut 'cacar' tersebut dengan cangkrim pada masyarakat daerah Jimbaran dan Kedonganan namun disebut gumpangan pada masyarakat usia tua di daerah Ungasan. Hal yang sama terjadi pada kata 'ketombe' yang mengalami variasi penyebutannya antara masyarakat golongan tua dan muda. Ketombe dalam penggunaan bahasa Bali ternyata masyarakat golongan usia muda tetap menyebutnya dengan ketombe begitu juga dengan masyarakat tua dengan mobilitas tinggi juga menyebut dengan ketombe. Hanya masyarakat golongan usia tua yang mobilitasnya kurang menyebut ketombe dengan bahasa Bali yang lumbrah yakni lampah dan ada variasi penyebutan kata ketombe dengan 'kebun' di daerah Ungasan.

\section{Variasi Leksikal Jenis Kata Adverbia}

Adverbia atau kata keterangan merupakan segala kata 
Tabel 3.

Variasi Leksikal Jenis Kata Adverbia Dialek Kuta Selatan

\begin{tabular}{|c|c|c|c|c|c|c|c|c|c|c|}
\hline \multirow[t]{2}{*}{ No } & \multirow{2}{*}{$\begin{array}{l}\text { Jenis kata } \\
\text { Adverbia }\end{array}$} & \multicolumn{3}{|c|}{ Kedonganan } & \multicolumn{3}{|c|}{ Jimbaran } & \multicolumn{3}{|c|}{ Ungasan } \\
\hline & & TNM & TM & M & TNM & TM & M & TNM & TM & M \\
\hline 1 & Sore & Sanjé & sanjé & sanjé & sanjé & sanjé & sanjé & $\begin{array}{l}\text { Sanjano, } \\
\text { sanjanyo }\end{array}$ & sanjano & Sanjano \\
\hline 2 & Semua & $\begin{array}{l}\text { Konyan- } \\
\text { gan }\end{array}$ & $\begin{array}{l}\text { Kon- } \\
\text { yaangan }\end{array}$ & $\begin{array}{l}\text { konyan- } \\
\text { gan }\end{array}$ & onyé & onyé & onyé & $\begin{array}{l}\text { Konyangan, } \\
\text { onyang }\end{array}$ & $\begin{array}{l}\text { Konyan- } \\
\text { gan }\end{array}$ & $\begin{array}{l}\text { konyan- } \\
\text { gan }\end{array}$ \\
\hline 3 & Tengah hari & téngai & Téngai & téngai & $\begin{array}{l}\text { Kali } \\
\text { tépét }\end{array}$ & $\begin{array}{l}\text { Kali } \\
\text { tépét }\end{array}$ & Kali tépét & $\begin{array}{l}\text { Téngah tépot, } \\
\text { téngai }\end{array}$ & téngai & téngai \\
\hline 4 & Dini hari & Plimunan & Séméng & Séméng & Plimunan & séméng & $\begin{array}{l}\text { Séméng, } \\
\text { plimunan }\end{array}$ & sémongan & $\begin{array}{l}\text { Sémon- } \\
\text { gan }\end{array}$ & $\begin{array}{l}\text { sémon- } \\
\text { gan }\end{array}$ \\
\hline 5 & Di belakang & Di duri & Di duri & Di duri & Di duri & Di duri & Di duri & Di juri & Di juri & Di juri \\
\hline 6 & Bagaimana & engken & Engken & Engken & Engken & engken & Engken & $\begin{array}{l}\text { Kengen, ngen- } \\
\text { gen }\end{array}$ & Kengen & Kengen \\
\hline 7 & Di mana & Dijé & Dijé & Dijé & Dijé & dijé & Dijé & Di joho & Di joho & Di joho \\
\hline
\end{tabular}

yang menerangkan kata kerja, kata sifat, kta bilangan akan tetapi tidak menerangkan kata benda. Beberapa variasi kata keterangan (adverbia) yang ditemukan dalam penelitian ini adalah:

Leksikal yang digunakan masyarakat Jimbaran, Kedonganan dan Ungasan pada bentuk adverbianya tidak terlalu menunjukkan variasi yang signifikan, terutama pada daerah Jimbaran dan Kedonganan. Walau intonasi dan aksen masyarakat asli Jimbaran dan Kedonganan sedikit berbeda, namun leksikal yang digunakan hamper sama khususnya untuk bentuk adverbial atau kata keterangan. Variasi leksikal bentuk adverbial ini ditemukan di daerah Ungasan yang letak daerahnya lebih diatas atau di perbukitan di banding dua daerah bagian Kuta selatan lainnya ini. Untuk menyebut 'kemana' yang dalam bahasa Bali disebut dengan dijé, masyarakat Ungasan sebagian besar menyebutnya dengan dijoho begitu pula dengan kata 'sore' yang disebut dengan sanjé oleh masyarakat Jimbaran ataupun Kedonganan, namun di Ungasan disebut dengan sanjano.

Untuk menyebut 'bagaimana' masyarakat Kedonganan menyebut dengan kengken atau dengan variasi pemenggalan dengan menyebut engken, hal tersebut sama seperti tuturan masyarakat di daerah Jimbaran. Namun leksikal ini memiliki variasi unik dalam penyebutannnya di darah Ungasan. Masyarakat Ungasan biasa menyebut kengken atau engken dengan variasi kengen ataupun ngengen. Kata di duri 'di belakang' merupakan leksikal yang biasa digunakan dalam bahasa Bali untuk daerah-daerah lain, masyarakat Jimbaran dan Kedonganan pun menggunakan leksikal ini, namun temuan yang diperoleh di lapangan untuk kata di duri ini disebut dengan variasi di juri oleh penutur yang berasal dari Ungasan, baik oleh masyarakat usia tua yang mobilitasnya kurang ataupun yang tinggi dan juga pada golongan anakanak muda.

\section{Variasi Verba}

Kata kerja (verba) adalah kelas kata yang menyatakan tindakan, beberapa variasi kata kerja pada bahasa Bali dialek Kuta Selatan yang ditemukan dalam penelitian ini dapat dilihat dalam tabel jenis kata kerja dibawah ini. Tidak banyak variasi yang ditemukan, namun beberapa yang mewakili variasi leksikal verba ini untuk kata-kata seperti 'menelan', 'di dengar', 'garuk, 'menabuh' dan 'batuk'. Gélék atau ngélék meruoakan bahasa Bali dari menelan. Pada daerah Jimbaran dan Kedonganan tidak ada variasi yang ditemukan untuk leksikal ini, namun di Ungasan, bentuk biasa disebut dengan ngélokang. Dan 'mendengarkan' yang dalam bahasa Bali disebut dengan dingéh, namun variasi ditemukan di daerah Ungasan dengan penyebutan dingoho.

'Menggaruk' atau 'garuk' yang disebut dengan gagas, ditemukan variasi di daerah Jimbaran dan Ungasan, yakni terkadang disebut dengan gauk, terutama oleh 
Tabel 4.

Variasi Leksikal Jenis Kata Verba Dialek Kuta Selatan

\begin{tabular}{|c|c|c|c|c|c|c|c|c|c|c|}
\hline \multirow{2}{*}{ No } & \multirow{2}{*}{$\begin{array}{c}\text { Jenis kata } \\
\text { Verba }\end{array}$} & \multicolumn{3}{|c|}{ Kedonganan } & \multicolumn{3}{|c|}{ Jimbaran } & \multicolumn{3}{|c|}{ Ungasan } \\
\hline & & TNM & TM & $\mathbf{M}$ & TNM & $\mathbf{T M}$ & $\mathbf{M}$ & TNM & TM & $\mathbf{M}$ \\
\hline 1 & Menelan & $\begin{array}{l}\text { Gélék, } \\
\text { ngélék }\end{array}$ & $\begin{array}{l}\text { Gélék, } \\
\text { ngélék }\end{array}$ & $\begin{array}{l}\text { Gélék, } \\
\text { ngélék }\end{array}$ & $\begin{array}{l}\text { Gélék, } \\
\text { ngélék }\end{array}$ & $\begin{array}{l}\text { Gélék, } \\
\text { ngélék }\end{array}$ & $\begin{array}{l}\text { Gélék, } \\
\text { ngélék }\end{array}$ & $\begin{array}{l}\text { ngélo- } \\
\text { kang }\end{array}$ & $\begin{array}{l}\text { ngélo- } \\
\text { kang }\end{array}$ & $\begin{array}{l}\text { ngélo- } \\
\text { kang }\end{array}$ \\
\hline 2 & Di dengar & Dingéh & dingéh & Dingéh & Dingéh & Dingéh & dingéh & dingoho & dingoho & $\begin{array}{l}\text { dingo- } \\
\text { ho }\end{array}$ \\
\hline 3 & Garuk & Gagas & gagas & Gagas & Gagas & $\begin{array}{l}\text { Gauk, } \\
\text { gagas }\end{array}$ & gagas & gauk & gauk & $\begin{array}{l}\text { Gagas, } \\
\text { gauk }\end{array}$ \\
\hline 4 & Menabuh & Mégambél & mégambél & Mégambél & mégambél & mégambél & mégambél & mégamol & $\begin{array}{l}\text { méga- } \\
\text { mol }\end{array}$ & $\begin{array}{l}\text { méga- } \\
\text { mol }\end{array}$ \\
\hline 5 & batuk & Kokoan & $\begin{array}{l}\text { Kokoan, } \\
\text { dékah }\end{array}$ & $\begin{array}{l}\text { Dékah, } \\
\text { batuk }\end{array}$ & Dékah & Dékah & dékah & kohkohan & $\begin{array}{l}\text { kohko- } \\
\text { han }\end{array}$ & $\begin{array}{l}\text { kohko- } \\
\text { han }\end{array}$ \\
\hline
\end{tabular}

Tabel 5.

Variasi Leksikal Jenis Kata Adjektiva Dialek Kuta Selatan

\begin{tabular}{|c|c|c|c|c|c|c|c|c|c|c|}
\hline \multirow[t]{2}{*}{ No } & \multirow{2}{*}{$\begin{array}{l}\begin{array}{l}\text { Jenis } \\
\text { kata }\end{array} \\
\begin{array}{l}\text { Adjek- } \\
\text { tiva }\end{array}\end{array}$} & \multicolumn{3}{|c|}{ Kedonganan } & \multicolumn{3}{|c|}{ Jimbaran } & \multicolumn{3}{|c|}{ Ungasan } \\
\hline & & TNM & $\mathbf{T M}$ & M & TNM & $\mathbf{T M}$ & M & TNM & $\mathbf{T M}$ & $\mathbf{M}$ \\
\hline 1 & Kanan & $\begin{array}{l}\text { Ténga- } \\
\text { wan, } \\
\text { kénawan }\end{array}$ & $\begin{array}{l}\text { Ténga- } \\
\text { wan, } \\
\text { kénawan }\end{array}$ & $\begin{array}{l}\text { Ténga- } \\
\text { wan, } \\
\text { kénawan }\end{array}$ & téngawan & téngawan & téngawan & téngawan & $\begin{array}{l}\text { Téngawan/ } \\
\text { kénawan }\end{array}$ & $\begin{array}{l}\text { Téngawan/ } \\
\text { kénawan }\end{array}$ \\
\hline 2 & Sebentar & $\begin{array}{l}\text { Kéjép, } \\
\text { bin jép }\end{array}$ & $\begin{array}{l}\text { Kéjép, } \\
\text { bin jép }\end{array}$ & $\begin{array}{l}\text { Kéjép, } \\
\text { bin jép }\end{array}$ & $\begin{array}{l}\text { Enjép, } \\
\text { Kéjép, bin } \\
\text { jép }\end{array}$ & $\begin{array}{l}\text { Enjép, } \\
\text { Kéjép, } \\
\text { bin jép }\end{array}$ & $\begin{array}{l}\text { Enjép, } \\
\text { Kéjép, } \\
\text { bin jép }\end{array}$ & $\begin{array}{l}\text { Géjop, bin } \\
\text { géjop }\end{array}$ & $\begin{array}{l}\text { Kéjop, bin } \\
\text { kéjop }\end{array}$ & $\begin{array}{l}\text { Kéjop, bin } \\
\text { kéjop }\end{array}$ \\
\hline 3 & gelap & péténg & péténg & Péténg & péténg & péténg & péténg & Pétong & pétong & pétong \\
\hline
\end{tabular}

masyarakat usia tua yang tingkat mobilitasnya sangat rendah. Kemudian untuk leksikal 'batuk' di daerah Jimbaran disebut dengan dékah, sedangkan di Ungasan biasa disebut dengan kohkohan, namun di Kedonganan kombinasi penggunaan variasi ini digunakan. Kata 'menabuh' yang dalam bahasa Bali disebut dengan mégambél, di Ungasan sangat khas disebut dengan mégamol.

\section{Variasi Leksikal Jenis Adjektiva}

Variasi kata keadaan atau sifat (adjektiva) dalam data penelitian ini terdapat pada kata kénawan, kéjép dan péténg yang dalam bahasa Indonesia berarti 'kanan', 'sebentar', dan 'gelap'.
Penyebutan 'kanan' pada tiga daerah di wilayah Kuta bagian Selatan ini engalami variasi. Masyarakat setempat menyebutnya dengan téngawan ataupun kénawan. Kata 'sebentar' dalam bahasa Bali lumbrah disebut dengan kéjép atau bin kéjép, namun dalam penggunaannya, penutur dari daerah Jimbaran dan Kedonganan sering melakukan pemenggalan dari bentuk utuh kéjép menjadi enjép atau bin kéjép menjadi bin jép, hal tersebut berbeda dengan di daerah Ungasan yang disebut dengan kéjop atau bin kéjop. Kata péténg yang berarti gelap juga menjadi vaiasi pétong di daerah Ungasan. 


\section{SIMPULAN}

Variasi bahasa Bali dialek Kuta bagian Selatan yakni pada daerah Jimbaran, Kedonganan dan Ungasan banyak diperoleh pada penggunaan bahasa Bali kepara. Karena pada tataran ini penuturnya tidak terikat oleh aturan dalam mengungkapkan atau pemilihan kata. Tuturan dalam keadaan nonformal juga menimbulkan lebih banyak dialek yang terungkap, dan faktor lawan tutur juga menjadi faktor penyebab dialek masing-masing daerah lebih terdengar. Jika penutur berbicara dengan lawan tutur yang berasal dari daerah yang sama, maka tampak penutur lebih bebas dalam pemilihan kata. Latar budaya yang sama antar penutur ternyata menjadikan pilihan kata ataupun dialek bahasa lokal menjadi lebih terdengar.

Variasi leksikal dalam mengungkapkan kata ganti atau pronominal pada masing-masing daerah yang diteliti dan variasi penggunaan pronominal juga ditemukan berdasarkan usia dan tingkat keakraban penutur dengan lawan tuturnya. Pada jenis kelas kata yang lain ditemukan variasi pada beberapa kata benda atau nomina, kata sifat, kata kerja dan kata keterangan. Pada dialek Jimbaran dan Kedonganan banyak ditemukan penggunaan leksikal dan variasi bunyi yang sama. Hal tersebut terjadi karena daerahnya yang bersebelahan, namun tetap saja terdapat perbedaan dari segi aksen. Pada dialek Ungasan ditemukan lebih banyak perbedaan leksikal yang digunakan untuk merujuk suatu yang sama, hal tersebut dipengaruhi karena struktur bunyi dialek Ungasan yang sangat khas dan letak daerahnya yang berada lebih jauh dari pusat kota. Letak desa Ungasan yang berada di dataran yang lebih tinggi juga menjadi faktor lebih banyaknya variasi leksikal dan bunyi yang ditemukan yang bunyi serta bentuknya sangat khas. Masyarakat dengan tingkat mobilitas rendah tetap menunjukkan penggunaan bahasa Bali dengan dialek Ungasan yang kental namun masyarakat yang tingkat mobilitasnya tinggi menjadi memiliki variasi yang lebih banyak dalam mengungkapkan sesuatu. Selain faktor lokasi dan keformalan, faktor usia dan mobilitas juga menjadi faktor dominan yang menyebabkan terjadinya variasi leksikal dan bunyi pada masing-masing dialek. Penggunaan bahasa Indonesia di sekolah ataupun bahasa Inggris oleh masyarakatnya terutama pada penutur usia muda menyebabkan beberapa kata tidak bisa menyebutkan bahasa Bali dari entitas yang ditanyakan. Untuk variasi bunyi lebih banyak dapat terungkap dalam penelitian ini, terutama yang ditemukan dalam tuturan langsung (percakapan) antara penutur dari daerah yang sama.

\section{DAFTAR RUJUKAN}

Chaer, Abdul. 2003. Lingusitik Umum. Jakarta:Rineka Cipta

Chambers,J.K.N dan Trudgill, Peter.1980. Dialektologi.Chambridge: University Press.

Denes, I Made, dkk. 1985. Dialek Geografi Bahasa Bali. Jakarta: Pusat Pembinaan dan

Pengembangan Bahasa Departemen Pendidikan dan Kebudayaan.

Kramsch, Claire. 1998. Language and Culture. Oxford: Oxford University Press.

Kridalaksana, Harimurti.2008. Kamus Linguistik. Jakarta:PT.Gramedia Pustaka Utama.

Kurniati, Endang dan Haribakti Mardikantoro. 2010. "Pola Variasi Bahasa Jawa (Kajian

Sosiodialketologi pada Masyarakat Tutur di Jawa Tengah)". Humaniora. 22 (3), 273-284

Nadra dan Reniwati. 2009. Dialektologi Teori dan Metode. Yogyakarta: CV Elmatera

Simanjuntak, Mangantar. 1990. Teori Fitur Distingtif dalam Fonologi Generatif: Perkembangan dan Penerapannya. Jakarta: Gaya Media Pratama.

Spolsky, Bernard. 2003.Sociolinguitics. New York: Oxford University Press.

Sudaryanto. 1988.Metode Linguistik Bagian I. Yogyakarta: Gajah Mada University Press.

Sudaryanto. 1993. Metode dan Anea Teknik Analisis Bahasa, Pengantar Penelitian Wahana

Kebudayaan Secara Linguistik. Yogyakarta: Duta Wacana University Press.

Wiladati, Ribka Andresti. 2014. "Bahasa Jawa di Kabupaten Batang (Tataran

Fonologi dan Leksikon)". Sutasoma Jurnal of Japanese Literature. 3 (1), 1-5.

Yadnya, Putra. 2004. "Menuju Linguistik Kebudayaan sebagai Ilmu: Sebuah Perspektif Filsafat Ilmu". dalam Bahasa dalam Perspektif Kebudayaan. Denpasar: Universitas Udayana. 